\title{
Waste Management in Ancient Times and Today from the Perspective of Teachers: Reflections to Diaries
}

Dilek Erduran Avcı

Huriye Deniş Çeliker

Mehmet Akif Ersoy University,

Education Faculty, Science Education

Department, Burdur/Turkey.

\begin{abstract}
Wastes, which are results of human activities, have reached to amounts that threaten the lives of current and future human generations. The only way to create a waste-aware and recycling-aware society is through the education of our children. At this point, science teachers have a key role in formation of recycling generation. With this fact in mind, Project "Look forward, recycle: Recycler teacher" was conducted to make teachers witness the effects of two lifestyles, with and without wastes, to increase their knowledge on the issue, and to develop positive behavior about recycling. This project was conducted with the support of Scientific and Technological Research Council of Turkey and Mehmet Akif Ersoy University in Burdur during August, 2014. Twenty teachers from different provinces of Turkey participated in the project activities. Nature trainings included 23 activities and they were conducted by academic consultancy. In this process, participant teachers wrote diaries about the assigned subjects after completing their daily activities. Diary topics were determined in such a way that the participants could convey their feelings and opinions about the daily activity content. This study covers the results of five activity events and written diaries about them since the activity topics and contents were comprehensive. The names of these five events are as follows: (1) Let us trace the wastes, (2) Where to our wastes travel?, (3) Irregular and regular storage, (4) A journey in history: Introduction to the ancient city of Kibyra, and (5) Waste and waste management in ancient times. Teachers wrote diaries about the subject "Can you compare waste and waste management between ancient times and today?" after completing five events. The analysis of the diaries indicated that almost all teachers displayed an increased awareness and knowledge about waste and recycling increased by means of activities performed in modern technological facilities (purifying, waste collection facilities, wild-landfill storage areas) and historical remains. However, many teachers stated that still standing sewerage system made up of soil and stone of Kibyra ancient city and solid waste landfill site called as Bothros interested them much more rather than the modern technological system. Obviously teachers found waste management of ancient times much nature-friendly in comparison to the modern era.
\end{abstract}

Keywords: Waste management, recycling, modern technological facilities, ancient times, teachers.

\section{Introduction}

Wastes, which are produced as the results of human activities, have reached to an extend that threatens the lives of the generations of both today and the future (Court of Accounts, 2007). Together with using economic recovery methods like reuse of the wastes, recycling, composting, or energy production, preventing the rapid consumption of natural resources and producing wastes which do not threaten human and environmental health form the basis of "sustainable development". Efficient recovery can be possible by degradation at the source (Court of Accounts, 2007). This fact focuses on conscious consumption behaviors (Bayazit Hayta, 2009). Making each member of our society a recycling-aware consumer can only be achieved by educating our children. The focus of Turkish secondary school science course curriculum has been "educating science literate individuals who have sustainable development awareness" since 2005 (MEB, 2005, 2013). The acquisitions regarding recycling, wastes, sustainability, and other related topics in the curriculum have gained more importance since then. In this context, science course teachers have one of the key roles in shaping a recycling generation (Erduran Avcı \& Deniş Çeliker, 2015). 
Although there are still locations in Turkey, where wastes could not be gathered and disposed of in accordance with the applicable legislation, efforts and effective applications are conducted in various provinces regarding solid waste storage areas and recycling (Ministry of Environment and Forestry, 2008). Burdur is one of the provinces that started such applications. Both sides of the coin, the negative effects on the nature caused by not recycling wastes and not storing them properly and the efforts to recycle wastes at their source together with the proper storage sites, can be observed in Burdur. This study presents some of the results of a nature training project which was conducted in Burdur. The aims of the project are (i) to make science course teachers experience that living with or without wastes has effects on humans, plants, animals, and environment, (ii) to improve their scientific perspective about this subject, and (iii) to make them gain positive attitude about recycling.

\section{"Look forward, recycle: Recycler teacher" Project}

"Look forward, recycle: Recycler teacher" project was conducted from 17th to 23rd August 2104 in Burdur with the support of Scientific and Technological Research Council of Turkey and Mehmet Akif Ersoy University. Twenty science course teachers participated in 23 project activities during their nature training. These activities included discussions about living with and without wastes, facility inspection visits (waste concentration center, waste water treatment facility, solid waste storage areas, etc. ), on-hand activities (composting, producing bio-gases), land and water resource inspection visits (Lake Burdur and Lake Karaçal), and historical site inspection visits.

Wastes and waste management was a problem of ancient people as it is of us today. In this context, teachers tried to understand the approach of ancient people to this problem by visiting the ancient city of Kibyra near Gölhisar, Burdur. During this process, teachers wrote down diaries on given topics after completing the activities. The diary topics were determined as to make the participants express their ideas and opinions on the activity of the day.

Since the number of activities in the project is high, this article is bounded by five activities and the diary results about them. These activities are (1) Let us trace the wastes, (2) Where to our wastes travel? (3) Irregular and regular storage, (4) A journey in history: Introduction to the ancient city of Kibyra, and (5) Waste and waste management in ancient times.

The participants performed their activities regarding the contemporary waste management in waste concentration center, waste water treatment center, and irregular storage area (city dump). They performed their activities regarding waste management in ancient era in Kibyra ancient city. They wrote the diaries after performing their activities about comparing modern waste management with ancient waste management.

\section{Method}

This research is a qualitative study. Twenty volunteer science course teachers participated in the study. 13 of the teachers were male and 7 of them were female. The teachers applied for participation using an application form on the internet. The diaries written by the teachers were used as the data collection tools and their content were analyzed using content analysis. The themes, which were extracted via analysis, were supported by the expressions from teacher diaries. Nicknames were used instead of real names for quotes.

\section{Findings}

There were four major themes in science course teachers' diaries: learning, self-criticism, emotion, and comparison of ancient and modern eras. Table-1 presents the themes in the diaries and their distribution. 
Table 1. Themes and their distribution

\begin{tabular}{|c|c|c|}
\hline \multicolumn{2}{|l|}{ Themes } & $\mathbf{N}$ \\
\hline \multicolumn{2}{|l|}{ Learning } & 20 \\
\hline \multicolumn{2}{|l|}{ Self-criticism } & 13 \\
\hline \multicolumn{2}{|l|}{ Emotion } & 8 \\
\hline Ancient-Modern Era & Nature perception & 14 \\
\hline \multirow[t]{2}{*}{ Comparison } & Waste types & 7 \\
\hline & Waste gathering and recycling methods & 19 \\
\hline
\end{tabular}

$\mathrm{N}$ : Number of teachers

\section{Learning}

Most of the project activity participants stated that they had the opportunity to learn many concepts about which they had non-decent information of misconceptions. The most common of these concepts were bio-degradation, recycling, compost, solid waste storage methods, water treatment, waste types, bio-gas, and bacteria. During the project, teachers both saw the application of the theoretical information they received and sometimes had on-hands experience. They stated that this helped the retention of their newly gained knowledge. Some samples of diary entries are as follows:

We learnt a lot about bio-degradation and making compost. I learnt that oxygen is required for degradation and burning is not possible in areas to which oxygen does not penetrate. (Kahraman)

The activities and research trips we performed blended entertainment with information and they prove that retentive learning is possible this way. (Fatime)

We went to the solid waste storage area and could not believe our eyes. There were fumes everywhere. We learnt that the cause of the fumes was methane originating from the dump. We observed the difference between irregular and regular storage. (Özgür)

I learnt how bio-degradation occurred and how house wastes are reused via composting. (Tolga)

I learnt how wastes are recycled and in which areas they are used. (Sait)

Today I added a term, whose meaning I did not know, to my vocabulary: compost. (Aylin)

\section{Self-criticism}

The teachers expressed that they did not have enough information about wastes and recycling. Moreover, they stated that they were not aware of the way these information affected our daily lives and our environment. Some of the teachers made their own criticism by confessing that they did not make use of their information and skills sensitively. They said that they realized the negative results of their negligent behaviors on nature. Some samples from teachers' expressions which reflected self-criticism are as follows: 
We went to package storing. What a great effort and a great challenge. We act lazily at home and do not parse them but they struggle in that smell and dirt and do it. I will be very careful. . . To make a general evaluation, this was a very beneficial training. I witnessed and learnt many things I did not know about recycling. I will be very keen on this issue at home and at my school. . . We are sinking our world unconsciously. (Hünkar)

We were always deceiving ourselves. It was not the global warming, but our negligence and laziness that polluted the nature. (Özgür)

After seeing the waste water treatment facility I realized that there were many things I did not know. (Tolga)

This activity made me realize the extend the recycling box affected our lives. (Büşra)

If we give back what nature gave us, nature will show us her generosity. (Recep)

Now I am more aware of waste collection and parsing. (Bilge)

The greatest contribution of this training to me is that: I will return back to my students with more information about recycling, a topic I thought I knew, I will share them with my students, and I will educate more conscious students and make them more aware citizens. (Yaşar)

\section{Emotion}

Teachers made some emotionally negative expressions in their diaries about the places they saw, the information they gained, and the applications they made during the project activities. These expressions indicate that they experienced fear, anxiety, and distress. Some examples of such expressions are as follows:

This was the first time I wandered around in a dump. I was like watching the backstage of the people who paid great attention to how they looked and the results of their activities. The bad smell in the dump, the slowly burning fire there, and the dead creatures around were like the mourning of universe to humanity. I thought we might die somewhere among the wastes surrounding the world and I was very touched by it. (Jale)

We observed the journey of the sewer water in the treatment facility until it becomes clean again. We could not believe what we saw. We inspected how that dirty water which contained solid wastes became clean water again. (Özgür)

I noticed that the current status of Lake Burdur was catastrophic and it was about to dry. (Bilge)

I feel more disturbed every passing day by the waste density in Turkey, the increasing waste amount due to population and unconscious consumption. (Zeynep)

As the result of today's activities, I learnt that the living style of people can be unearthed even after centuries. I am afraid archeologists will speak about how a primitive society we were and how we polluted the nature after unearthing cities of Turkey as ancient cities. (Ismihan)

We started the day with the water treatment facility. ... yesterday we went around Lake Burdur and saw no water resource feeding it. Today we learnt that it was only fed by waste water. What will our heritage be to the future generations? I think our wastes will be our only heritage. (Ömer)

\section{Comparison of ancient and modern eras}

While comparing Kibyra ancient city and modern age of today, teachers heavily criticized modern era. The analysis of the diaries show that this comparison can be categorized to three sub-themes as 'nature perception', 'waste types', and 'waste gathering and recycling methods'.

First of these sub-themes is named as nature perception. Teachers compared the activities of two eras which are performed in order to manage wastes. Most of them found the waste management in ancient Kibyra far more natural than modern Burdur. For instance, İsmihan expressed her opinion regarding this issue as "...I think that the people of the ancient ages were far more environment-friendly than us despite they lacked today's technology and opportunities. After today's 
activities, I learnt that the living styles of people can be understood even after centuries by excavations. I am afraid archeologists will speak about how a primitive society we were and how we polluted the nature after unearthing cities of Turkey as ancient cities". Özgür stated the difference between the nature perception of the people of two different eras as "the people of that age cared about the nature more than us. . I managed to see the emphasis that people of ancient times put on art, sports, and environment by observing the theaters, sewer systems, and stadiums they built. I am both happy and sad to see that such people lived on our lands because we cannot see such things in our modern society. Theaters are replaced by television, not even by cinema. We consider only football as sports. Would it be better if we lived in the ancient age?".

The second theme is waste types. Teachers stated that the wastes of ancient era were mostly organic ones which can degrade in nature easily where the wastes of today were various and not nature-friendly. They compared the waste types of two periods by giving examples. For instance, Zeynep wrote: "There are some materials like plastic, glass, metal, or batteries that cannot be recycled enough. They were not used in the ancient times but today we cannot think a life without them. "Büşra expressed her observations and her admiration as "The wastes in the ancient era were very natural. Wastes were either remnants of food or pottery which were made of mud. They used to gather them in specific locations. Food remnants were used as fertilizers and the other wastes were transformed to sand in order to be used in grout as a construction material. The waste water was drained from the city regularly via a major channel fed by smaller channels. Today the case is not that easy and healthy. Today I was surprised by every site I saw. I was amazed once again after telling myself that there should not be a more amazing place. " Bilge's opinions on the subject were as follows: "Ancient people did not kill their environment like us. There were no plastic and harmful gases were very limited. Even so they built regular sewer systems and waste storage areas. There is no need to say anything about today, especially about our country's status."

The last sub-theme is waste gathering and recycling methods. This sub-theme covers the comparisons between two eras regarding waste gathering and recycling methods. It was a remarkable fact that the teachers compared modern waste storage areas to ancient bothros fields and the materials of modern and ancient sewer and drainage systems. Most of the teachers were amazed by the methods used in ancient times. Regarding this issue, Jale wrote "There were waste gathering areas called "bothros" in ancient times similar to our modern world. They had water channels. But they had enhanced sewer systems water drainage pipes for public areas which we lack today. The ancient people used healthy pipes made of mud instead of today's plastic. "Merve expressed her observations in her journal as: "After seeing the ancient city of Kibyra's infrastructure and the place they gathered their wastes, I think that we are not that advanced today. They built the sewer system before building the city. It is a system that travels all the way underneath the city collecting the waste water and a person can traverse in it easily. Moreover, there are pipe systems to drain rain water beneath public places like the stadium. They were transporting the solid wastes which were produced in houses to some pre-determined areas in the city. These wastes were grinded in order to be reused as grout. Today, factory and business wastes are in huge amounts due to industrialization. Rapid increase in human population affects all creatures and natural environment indeed."

\section{Results}

This study presents some of the results of the activities which were performed during Project "Look forward, recycle: Recycler teacher", which compared waste management in modern and ancient times. Participant diaries were inspected in order to find out how teachers evaluated waste management in both eras. Results indicated that teachers' opinions could be categorized into for themes. These themes were learning, self-criticism, emotion, and comparison of ancient and modern eras. Most of the teachers stated that most of the concepts regarding recycling were new to them. Some of the teachers criticized themselves and they stated that their previous knowledge on the issue included many misconceptions. These teachers emphasized that they corrected their misconceptions during the project activities. Another topic about which teachers criticized themselves was not being conscious enough about the environment. They said that they understood the negative effects of their negligent behaviors on nature. This fact caused fear, anxiety, or distress to some of the teachers.

Teachers seriously criticized our modern age in means of harming the nature following the activities conducted in ancient city of Kibyra. Most of them considered the waste management in Kibyra ancient city more natural in comparison to modern era. Furthermore, one of the teachers explicitly expressed this fact by writing "... Would it be better if we lived in the ancient age". Many teachers were amazed by the waste storage and bothros fields, sewer systems, and water drainage pipes of 
ancient Kibyra city, all of which survived until today. Some of the teachers stated that waste types of modern era were compound of materials that can hardly degrade and stressed the negative effects of this difference to nature. In short, teachers sadly admitted that the people who lived in ancient city of Kibyra valued their nature more than we do today. The expressions in the diaries of participant teachers indicated that their knowledge, awareness, and consciousness about wastes, recycling and environment increased and they admired ancient era.

Waste management principles hierarchy, which forms the basis of European Union's waste management strategy and is adopted by our national legislation, outlines the basic policies of a healthy and effective waste management system. These principles include reducing the wastes at the source/preventing waste production, maximizing the reuse of the wastes that cannot be prevented by recycling, composting, or converting to energy, and safely storing the wastes that cannot be reused (Court of Accounts, 2007). These principles and targets can only be applied and achieved by the applications of local administrations. But the most important thing in this process is making every individual of the community believe and adopt it. Recycler teachers are the important keys to grow recycler students who will be recycler parents, leading to a recycler society. In this context, the expected outcome of this project is contributing to national targets by educating recycler students via teachers who have this vision.

Acknowledgements: This research project was conducted by the support of TÜBITAK School of Nature and Science Education in 2014 (Project number: 213B704). We would like to thank TÜBITAK, administrative personnel and academics of MAKÜ, Provincial Administration of Burdur, Burdur Municipality and its personnel, and to all of our participant teachers.

Note: Details about our project and Kibrya ancient city are available on http: //www. mehmetakif. edu. tr/projeler/ileriyebakgeridonustur/ and http: //www. burdur. gov. tr/kibyra. asp.

\section{References}

[1] Bayazıt Hayta, A. (2009). Sürdürülebilir tüketim ve aile. Türkiye Sosyal Araştırmalar Dergisi, 13 (3), 69-83.

[2] Erduran Avcı, D. \& Deniş Çeliker, H. (2015). The effect of recycler teachers project on scince teachers' attitude towards waste and recycling. Journal of Research in Education and Teaching. 4 (1), 215-224.

[3] Turkish Court of Accounts (2007). Waste management in Turkey: Performance audit report. Ankara: T. C. Sayıştay Başkanlığı. http: //www. sayistay. gov. tr/rapor/perdenrap/2007/2007-1AtikYonetimi/2007Atik_Yonetimi_Raporu.pdf

[4] Turkish Ministry of Education (2005). Elementary science and Technology course curriculum and handbook. Ankara, Turkey: Devlet kitapları müdürlüğü.

[5] Turkish Ministry of Education (2013). Secondary school science course curriculum. Ankara, Turkey: Talim Terbiye Kurulu Başkanlığı.

[6] Turkish Ministry of Environment and Forests (2008). Turkish waste management action plan (2008-2012). Anakara: T. C. Çevre ve Orman Bakanlığı. 